\title{
DAYA TERIMA MAKANAN PADA PASIEN DIABETES MELITUS TIPE 2 DENGAN KOMPLIKASI DI RUANG PERAWATAN INTERNAL RS MARDI WALUYO LAMPUNG
}

\author{
Gelora Mangalik $^{1)}$, Theresia Pratiwi Elingsetyo Sanubari ${ }^{2}$, Claudia Cipta Maharani ${ }^{3)}$ \\ ${ }^{122) 33}$ Program Studi Ilmu Gizi, Fakultas Kedokteran dan Imu Kesehatan, \\ Universitas Kristen Satya Wacana \\ E-mail: gelora.mangalik@uksw.edu
}

\begin{abstract}
Food Acceptance is a person's ability to spend food that is served following their needs. Low food acceptability can lead to the risk of malnutrition and affect the nutritional status and healing of patients. This study aims to identify the acceptability of food for patients with type 2 Diabetes Mellitus with complications in the internal care room at Mardi Waluyo Hospital in Lampung. The method used is descriptive quantitative with the cross-sectional design carried out to 53 respondents with a purposive sampling technique of sample collection. The study was conducted in March-April 2019. The results showed that research on respondents in this study showed that respondents mostly depend on the age range of 40-65 years by 65\%, 72\% of women, have a risk of disease $\geq 2$ of $68 \%$, and respondents who fall into the category of overweight and obesity by $47 \%$. Based on the average distribution of the rest of the respondent's food by $77.4 \%$, based on the attributes of food according to the good category with a value of $\geq$ $80 \%$. This study concludes that resources about leftovers in patients with type 2 diabetes with complications are not good with leftovers $\geq 25 \%$. Based on food attributes according to the good category.
\end{abstract}

Keyword: Food Acceptance; DM type 2 and Complication; Food attributes.

\begin{abstract}
ABSTRAK
Daya terima makan yaitu kesanggupan seseorang mampu menghabiskan makanan yang disajikan sesuai dengan kebutuhannya. Daya terima makanan yang rendah dapat terjadi risiko malnutrisi dan mempengaruhi status gizi serta kesembuhan pasien. Penelitian ini bertujuan untuk mengidentifikasi daya terima makanan pasien Diabetes Melitus tipe 2 dengan komplikasi di ruang perawatan internal RS Mardi Waluyo Lampung. Metode yang
\end{abstract}

Cara mengutip: Mangalik, Gelora., Sanubari, T.P. Elingsetyo., \& Maharani, C. Cipta. (2020). Daya Terima Makanan Pada Pasien Diabetes Melitus Tipe 2 Dengan Komplikasi Di Ruang Perawatan Internal RS Mardi Waluyo Lampung. Care:Jurnal Ilmiah Ilmu Kesehatan, 8(2), 222-234 
digunakan adalah deskriptif kuantitatif dengan desain cros-sectional dilakukan kepada 53 responden dengan teknik pengumpulan sampel purposive sampling. Penelitian dilakukan pada bulan Maret-April 2019. Hasil penelitian menunjukan bahwa berdasarkan karakteristik responden pada penelitian ini menunjukan bahwa usia sebagian besar responden berada pada kisaran umur 40-65 tahun sebanyak $65 \%$, berjenis kelamin perempuan $72 \%$, memiliki penyakit komplikasi $\geq 2$ sebanyak $68 \%$, dan responden yang masuk dalam kategori overweight dan obesitas sebesar $47 \%$. Berdasarkan ditribusi rata-rata sisa makanan responden secara keseluruhan tidak baik yaitu sebesar 77,4\%, Berdasarkan atribut makanan berada dalam kategori baik dengan nilai $\geq 80 \%$. Kesimpulan dari penelitian ini adalah daya terima makanan berdasarkan gambaran sisa makanan pada pasien DM tipe 2 dengan komplikasi yaitu tidak baik dengan sisa makanan $\geq 25 \%$. Berdasarkan atribut makanan berada dalam kategori baik

Kata Kunci : Daya terima makanan; DM Tipe 2 dengan Komplikasi; Atribut Makanan.

\section{PENDAHULUAN}

Rumah sakit adalah institusi pelayanan kesehatan yang berupaya memberikan pelayanan kesehatan yang memenuhi standar pelayanan yang optimal dan paripurna. Pelayanan kesehatan di rumah sakit merupakan kegiatan terpadu yang mencakup empat fungsi rumah sakit yaitu preventif, promotif, kuratif dan rehabilitatif dalam rangka meningkatkan kesehatan pasien. Pelayanan gizi yang dilaksanakan rumah sakit merupakan kegiatan kuratif (Kemenkes, 2013). Pelayanan gizi rumah sakit adalah pelayanan yang diberikan kepada pasien untuk mencapai kondisi yang optimal dalam memenuhi kebutuhan gizi pasien melalui makanan sesuai penyakit yang dideritanya. Pelayanan gizi rawat inap yaitu penyelenggaraan makanan bagi pasien yang dirawat (Sulistiyanto \& Oktia, 2017). Penyelenggaraan makanan dilakukan bertujuan untuk menyediakan makanan dengan kualitas baik, jumlah sesuai kebutuhan serta pelayanan yang layak dan memadai bagi pasien yang membutuhkan. Keberhasilan suatu penyelenggaraan makanan dapat dikaitkan dengan daya terima pasien terhadap makanan yang disajikan dan dapat dilihat dari jumlah sisa makanan, sehingga dapat dijadikan indikator sederhana untuk mengevaluasi keberhasilan pelayanan gizi di Rumah Sakit (Uyami et al., 2014).

Daya terima makanan merupakan kemampuan seseorang untuk menerima dan menghabiskan makanan tanpa meninggalkan sisa makanan. Rendahnya daya terima makanan akan berdampak bagi status gizi dan kesembuhan pasien, karena kurangnya asupan makanan. Daya terima makanan dapat dipengaruhi oleh kondisi pasien itu sendiri, seperti keadaan fisik dan klinis, sehingga resiko gizi kurang akan muncul secara klinis pada 
periode rawat inap di rumah sakit berkaitan dengan penyakit yang mendasarinya (Uyami et al., 2014).

Rumah Sakit Mardi Waluyo Lampung yang terletak di Provinsi Lampung, merupakan salah satu Rumah Sakit yang memperhatikan kualitas pelayanannya. Kualitas pelayanan ini dilihat dari pelayanan gizi dalam kegiatan penyelenggaraan makanan bagi pasien rawat inap. Dalam penyelenggaraan makanan pasien, diet pasien akan disesuaikan dengan jenis penyakitnya. Ada beberapa jenis diet bagi pasien, diet khusus merupakan salah satu diet bagi penderita DM. Penyakit DM merupakan salah satu penyakit dengan tingkat kejadian tinggi setelah penyakit jantung dan hipertensi, data yang diambil dari studi pendahuluan yang didapat dari Rumah Sakit Mardi Waluyo Lampung menunjukan bahwa pada tahun 2018 terjadi 989 kasus penyakit DM.

Diabetes Melitus adalah penyakit metabolik kronik dengan karakteristik hiperglikemia yang diakibatkan karena adanya kelainan yang terjadi pada sekresi insulin, kerja insulin, atau keduannya. Krieria DM ditegakkan apabila nilai Gula Darah Sewaktu (GDS) >200mg/dl, Gula Darah Puasa (GDP) >126 mg/dl, GD2PP >200mg/dl, TGT : glukosa darah plasma 2 jam setelah beban antara 140- 199 mg/dl, Glukosa Darah Puasa Terganggu (GDPT) antara $100-125$ mg/dl (DepKes RI, 2013). DM tipe 2 yaitu kelainan metabolik yang di tandai oleh kenaikan gula darah akibat penurunan sekresi insulin oleh sel beta pankreas serta ganguan fungsi insulin (Perkeni, 2011). Faktor resiko DM tipe 2 dikelompokkan menjadi tiga kelompok, yaitu sosiodemografi terdiri dari umur, biasa terjadi pada usia dewasa hingga lansia, serta jenis kelamin. Faktor perilaku dan gaya hidup seperti mengkonsumsi sayur dan buah, kebiasaan merokok, konsumsi alkohol dan aktivitas fisik. Keadaan klinis atau mental seperti indeks masa tubuh (kegemukan), lingkar pinggang (obesitas sentral) dan stres (Lathifah, 2017).

(WHO, 2016) memperkirakan pada tahun 2013 sebanyak 382.000 .000 orang telah menderita DM diseluruh dunia, dan jumlah tersebut akan bertambah hingga lebih dari 580.000.000 orang pada tahun 2035. Di Asia Tenggara terdapat 12,3 juta jiwa pada tahun 2011 diperkirakan meningkat menjadi hingga 19,4 juta jiwa pada tahun 2020. Indonesia di perkirakan akan menjadi 21,3 juta pada tahun 2030 dari 8,4 juta pada tahun 2008 (IDF, 2015). Indonesia diurutan ketujuh dalam 
daftar 10 negara dengan jumlah penderita DM terbesar di dunia. Prevalensi DM di Indonesia sebesar 2,1\%. Prevalensi DM di Provinsi Lampung sebanyak 0.7\% (Depkes, 2013). Dinas Kesehatan Provinsi Lampung mencatat jumlah penderita diabetes melitus pada tahun 2015 mengalami peningkatan sebesar 4\% (Depkes, 2015) Peningkatan kejadian komplikasi dipengaruhi oleh peningkatan kejadian DM. Komplikasi yang terjadi karena lamanya menderita DM menimbulkan sifat akut maupun kronis. Komplikasi akut terjadi saat penurunan atau peningkatan kadar gula darah seketika, sedangkan komplikasi kronis muncul dengan efek peningkatan kadar glukosa darah dalam jangka waktu lama. Komplikasi kronik dapat terjadi khususnya pada penderita DM tipe 2. Komplikasi kronik terjadi pada pembuluh darah besar (makrovaskuler) dan pembuluh darah kecil (mikrovaskuler). Komplikasi makrovaskuler yang terjadi pada penderita DM yaitu pembekuan darah di sebagian otak, penyakit jantung koroner, gagal jantung kongestif dan stroke, sedangkan untuk komplikasi mikrovaskuler yaitu hiperglikemia, nefropati diabetik, retinopati (kebutaan) dan neuropati (Smeltzer et al., 2010). Komplikasi dapat menyebabkan pendeknya rentang hidup, keterbatasan diri dan meningkatnya beban ekonomi bagi penderita dan keluarga, sehingga mempengaruhi penurunan kualitas hidup penderita bila tidak ditangani dengan baik (Wulan \& Wahyuni, 2017).

Upaya untuk memperoleh kesembuhan dari suatu penyakit, termasuk penyakit DM tipe 2 dengan komplikasi selain pengobatan, makanan merupakan salah satu faktor penunjang untuk proses penyembuhan penyakit dan mencegah terjadinya komplikasi DM kronis. Dengan mengkonsumsi makanan, berarti pasien mengkonsumsi zat gizi yang terkandung dimakanan tersebut. Tercukupinya zat gizi dapat membantu proses penyembuhan karena hal ini dapat menurunkan resistensi insulin dan meningkatkan kualitas hidup, namun masih terdapat penderita DM Tipe 2 dengan komplikasi yang belum dapat melaksanakan program diet yang telah diberikan, dapat dilihat dengan masih banyaknya sisa makanan pasien denga diet DM. Hasil penelitian Budiarti (2009) di RSUD kota Salatiga Jawa Tengah menunjukan sisa makanan sebanyak 53,1\%. Demikian juga penelitian Di RSUD Dr. H. Moch. Ansari Saleh Banjarmasin (Salman et al., 2014), ratarata sisa makanan pasien $>25 \%$ terdapat pada jenis makanan lauk nabati yaitu 
sebesar 55,6\%, lauk hewani dan buah sebesar $(51,1 \%)$. Hal ini yang mendasari penelitian mengenai daya terima pasien rawat inap penyakit DM tipe 2 dengan komplikasi terhadap makanan yang disajikan rumah sakit. Tujuan dari penelitian ini adalah untuk mengidentifikasi daya terima makanan pasien Diabetes Melitus tipe 2 dengan komplikasi di ruang perawatan internal RS Mardi Waluyo Lampung.

\section{METODE PENELITIAN}

Jenis Penelitian termasuk penelitian observasi dengan menggunakan penelitian deskriptif kuantitatif dengan desain crossectional yaitu rancangan penelitian yang dilakukan dalam satu kurun waktu tertentu. Penelitian dilaksanakan di Rumah Sakit Mardi Waluyo Lampung. Waktu penelitian dilakukan pada bulan Maret-April 2019. Penelitian dilakukan kepada 53 pasien rawat inap penyakit DM tipe 2 dengan komplikasi di RS Mardi Waluyo Lampung. Pemilihan sampel dilakukan secara purposive sampling berdasarkan kriteria dari subjek penelitian yaitu : penderita DM tipe 2 dengan komplikasi di RS Mardi Waluyo Lampung dengan keadaan umum pasien baik atau Compos Mentis (conscious), laki-laki dan perempuan, usia subjek 20-75 tahun, penderita dalam keadaan sadar, dan kooperatif, bersedia menjadi subjek penelitian dengan menandatangani informed-consent.

Alat ukur untuk mengetahui daya terima makanan adalah hasil sisa makanan pasien. Data primer meliputi Visual Comstock dengan skor skala 6 poin, Kategori daya terima makanan adalah baik (sisa makanan $<25 \%$ ) dan Tidak baik(sisa makanan $\geq 25 \%$ ) (Gobel et al., 2011), serta wawancara penilaian daya terima makanan terhadap atribut makanan. Data sekunder yang digunakan usia, jenis kelamin, komplikasi dan status gizi berdasarkan indikator IMT.Data yang telah di dapatkan selanjutnya akan di analisis. Analisa data dilakukan dengan reduksi data, penyajian data, penarikan kesimpulan, dan verifikasi.

\section{HASIL}

Berdasarkan Tabel 1 menunjukan bahwa usia responden sebagian besar berada pada kisaran umur 40-65 tahun(65\%), berjenis kelamin perempuan (72\%), memiliki penyakit komplikasi $\geq 2(68 \%)$, responden yang beresiko obesitas, obesitas 1, obesitas 2 (47\%).

Pada Tabel 2 menunjukan hasil yaitu tidak baik (sisa makanan $\geq 25 \%$ ). 
Makanan pokok bersisa $(75,5 \%)$, lauk $\quad(64,4 \%)$.

hewani $(79,2)$, lauk nabati $(64,2 \%)$, sayur

Tabel 1. Distribusi karakteristik responden berdasarkan usia, jenis kelamin, komplikasi dan status gizi berdasarkan IMT

\begin{tabular}{|c|c|c|}
\hline Karakteristik & $\mathrm{f}$ & $(\%)$ \\
\hline \multicolumn{3}{|l|}{ Usia } \\
\hline 20-40 Tahun & 0 & 0 \\
\hline 40-65 Tahun & 45 & 85 \\
\hline >65 Tahun & 8 & 15 \\
\hline \multicolumn{3}{|l|}{ Jenis Kelamin } \\
\hline Laki-laki & 15 & 28 \\
\hline Perempuan & 38 & 72 \\
\hline \multicolumn{3}{|l|}{ Komplikasi } \\
\hline 1 Komplikasi & 17 & 32 \\
\hline$\geq 2$ Komplikasi & 36 & 68 \\
\hline \multirow{2}{*}{\multicolumn{3}{|c|}{$\begin{array}{l}\text { *Status Gizi berdasarkan } \\
\text { IMT }\left(\mathrm{kg} / \mathrm{m}^{2}\right)\end{array}$}} \\
\hline & & \\
\hline Berat Badan Kurang $(<18,5)$ & 5 & 9 \\
\hline Berat Badan Normal $(18,5-$ & & \\
\hline 22,99$)$ & 23 & 43 \\
\hline Bersiko Menjadi Obese $(23,0-$ & & \\
\hline 24,99$)$ & 7 & 13 \\
\hline Obese I $(25,0-29,99)$ & 16 & 30 \\
\hline Obese II $(>30,0)$ & 2 & 4 \\
\hline
\end{tabular}

Tabel 2. Distribusi sisa makanan responden berdasarkan jenis bahan makanan

\begin{tabular}{lcc}
\hline *Jenis Sisa Makanan & f & (\%) \\
\hline Makanan Pokok & & \\
Baik (sisa makanan < 25\%) & 13 & $24,5 \%$ \\
Tidak baik (sisa makanan $\geq 25 \%)$ & 40 & $75,5 \%$ \\
Lauk Hewani & & \\
Baik (sisa makanan <25\%) & 11 & $20,8 \%$ \\
Tidak baik (sisa makanan $\geq 25 \%)$ & 42 & $79,2 \%$ \\
Lauk Nabati & & \\
Baik (sisa makanan <25\%) & 19 & $35,8 \%$ \\
Tidak baik (sisa makanan $\geq 25 \%)$ & 34 & $64,2 \%$ \\
Sayur & & \\
Baik (sisa makanan <25\%) & 21 & $39,6 \%$ \\
Tidak baik (sisa makanan $\geq 25 \%)$ & 32 & $60,4 \%$ \\
\hline
\end{tabular}

Sumber: Data pribadi, diolah (2019) dan *Gobel et al., 2011.

Pada Tabel 3 hasil rata-rata sisa makanan

secara keseluruhan yaitu menunjukkan

hasiltidak baik (sisa makanan $\geq 25 \%$ ) sebanyak $(74 \%)$.
Tabel 3. Distribusi rata-rata sisa makanan responden secara keseluruhan

\begin{tabular}{lcc}
\hline *Sisa makan & f & $\mathbf{( \% )}$ \\
\hline Baik & 12 & 22,6 \\
$($ sisa makanan $<25 \%)$ & & \\
$\quad$ Tidak baik & 41 & 77,4 \\
$\quad$ (sisa makanan $\geq 25 \%)$ & & \\
$\begin{array}{l}\text { Sumber: Data pribadi, diolah (2019) dan } \\
\text { *Gobel et al., 2011 }\end{array}$
\end{tabular}


Pada Tabel 4 data rata-rata penilaian daya terima makanan terhadap atribut makanan secara keseluruhan diperoleh hasil baik $\geq 80 \%$ (55\%).

Tabel 4. Distribusi penilaian terhadap atribut makanan secara keseluruhan

\begin{tabular}{ccc}
\hline $\begin{array}{c}\text { *Penilaian Daya } \\
\text { Terima }\end{array}$ & $\mathbf{f}$ & $\mathbf{( \% )}$ \\
\hline Baik $\geq 80 \%$ & 29 & 55 \\
Cukup $60-80 \%$ & 24 & 45 \\
Kurang $<60 \%$ & 0 & 0 \\
\hline
\end{tabular}

Sumber: Data pribadi, diolah (2019), *Sarma (2003) dan Munawar (2011)

\section{PEMBAHASAN}

\section{Karakteristik}

Responden

BerdasarkanUsia, Jenis Kelamin, Komplikasi Penyakit dan Stats Gizi

Pada penelitian ini diketahui bahwa ratarata responden adalah pasien yang berusia 40-65 tahun, yaitu sejumlah 45 responden (85\%). MenurutDepkes RI (2009) usia 40-45 tahun termasuk usia dewasa akhir, usia 46-55 tahun masa lansia awal dan usia 56-65 tahun masuk dalam masa lansia akhir, artinya dalam penelitian ini responden yang menderita penyakit DM tipe 2 dengan komplikasi mayoritas terjadi pada kategori usia pralansia hingga lansia. Penelitian yang dilakukan oleh Saepuloh (2003) menyatakan bahwa ada pengaruh antara daya terima pasien terhadap makanan dengan umur pasien, kepekaan indra seseorang terhadap bau dan rasa akan berkurang seiring dengan bertambahnya usia, sehingga dapat mempengaruhi rendahnya asupan makan dan menimbulkan sisa makanan.

Pada penelitian diketahui presentase terbanyak untuk penderita DM tipe 2 dengan komplikasi yaitu perempuan sebanyak 38 responden (72\%) (Tabel 1). Perempuan memiliki risiko lebih tinggi untuk mengalami gangguan sensitivitas insulin karena dipengaruhi oleh hormon esterogen selama siklus menstruasi, kehamilan, dan masa perimenopause, apabila terjadi peningkatan kadar esterogen, sekresi hormon epinefrin juga akan meningkat. Hormon epinefrin mempunyai efek metabolik seperti hormon glukagon yaitu meningkatkan kadar glukosa dalam darah melalui glukoneogenesis dan glikogenolisis yang dapat berlanjut menjadi DM tipe 2 (Irwan, 2010). Menurut Galleta (2005) daya terima makanan pada perempuan lebih rendah dari pada laki-laki dikarenakan perbedaan kebutuhan energi, dimana kalori basal perempuan lebih rendah dari kebutuhan kalori basal lakilaki. Perbedaan ini dilihat dari susunan tubuh, aktivitas, laki-laki banyak menggunakan kerja otot daripada perempuan, sehingga dalam mengkonsumsi makanan maupun 
pemilihan jenis makanan, perempuan dan laki-laki mempunyai selera yang berbeda(Priyanto, 2009).

Selain jenis kelamin dan usia, kondisi fisik juga mempengaruhi sisa makanan. Menurut Stanga et al. (2003) perubahan kondisi fisik sangat berperan terhadap sisa makanan, karena berhubungan dengan keinginan dan kemampuan individu dalam mengonsumsi suatu makanan. Pada penelitian ini responden dalam keadaan dirawat dengan kondisi fisik yang lemah dan memiliki penyakit DM tipe 2 dengan komplikasi. Distribusi penyakit komplikasi tertinggi adalah terkena $\geq 2$ komplikasi sebanyak 36 responden (68\%) (Tabel 1). Akibat kondisi fisik, masih banyak responden yang meninggalkan sisa makanan dan memiliki daya terima makanan rendah. Uyami et al. (2014) menyatakan rendahnya daya terima makanan pasien akan berpengaruh pada status gizi dan kesembuhan pasien, karena kurangnya asupan makanan. Selain itu daya terima makanan dapat dipengaruhi oleh kondisi pasien itu sendiri, seperti keadaan fisik dan klinis, sehingga resiko gizi kurang akan muncul secara klinis pada periode rawat inap di rumah sakit berkaitan dengan penyakit yang diderita. Berdasarkan penelitian yang dilakukan, responden yang beresiko obesitas, obesitas 1, obesitas 2 berjumlah 25 responden (47\%) (Tabel 1. Kondisi tersebut disebabkan oleh proses fisiologi tubuh responden yang menua, sehingga terdapat perubahan komposisi tubuh yang mengakibatkan kehilangan massa otot secara progresif (Sundariet al.,2015). Menurut Ramadhani (2016) bahwa kehilangan massa otot pada lansia dapat meningkatkan jaringan lemak yang berakibat penurunan pembentukan glikogen di otot. Oleh karena itu dapat diartikan, penumpukan lemak pada responden dalam penelitian ini yang beresiko obesitas, obesitas 1 , obesitas 2 tidak berkaitan dengan hasil daya terima makanan yang rendah. Namun, dikarenakan proses kehilangan massa otot yang dialami oleh pralansia dan lansia.

\section{Daya Terima Makanan Berdasarkan} Sisa Makanan Pada Jenis Bahan Makanan

Berdasarkan rata-rata sisa makanan responden dilihat dari jenis bahan makanan yaitu, bersisa $\geq 25 \%$ baik makanan pokok, lauk hewani, lauk nabati, dan sayur (Tabel 2). Makanan pokok bersisa $\geq 25 \%$ adalah 40 responden. Makanan pokok merupakan komponen yang paling banyak mengandung karbohidrat.Karbohidrat adalah suatu zat 
gizi yang fungsi utamanya sebagai penghasil energi. Energi sangat bermanfaat bagi tubuh, yaitu berguna untuk menggerakkan tubuh serta proses metabolisme didalam tubuh, jika konsumsi energi yang kurang dari kecukupan atau berada pada kategori defisit dapat mengkuatirkan bagi tubuh responden, karena akan membuat responden lemas dan tidak bertenaga sehingga dapat memperlambat proses penyembuhan dan memperlama masa perawatan di rumah sakit. Pada penelitian ini sebagian besar responden masih meninggalkan sisa makanan, artinya asupan responden dari makanan pokok masih kurang. Menurut Perkeni (2011), penderita DM tidak dianjurkan asupan energi lebih ataupun kurang dari kebutuhan. Apabila energi dari makanan pokok masih kurang tercukupi dapat dibantu dengan mengkonsumsi lauk hewani dan lauk nabati untuk memenuhi kebutuhan penderita DM tipe 2.

Pada penelitian, hasil sisa makanan lauk hewani $\geq 25 \%$ sebanyak 42 responden dan lauk nabati bersisa $\geq 25 \%$ yaitu 34 responden. Lauk hewani merupakan komponen makanan yang mengandung lemak dan protein yang mana lemak dapat meningkatkan glukosa darah melalui peningkatan resistensi insulin
(Harding et al., 2001). Menurut Dedoussis et al. (2007) setiap jenis lauk hewani memiliki kandungan lemak yang berbeda, dengan efek pada tubuh yang berbeda. Lemak jenuh memiliki efek meningkatkan resistensi insulin dan juga obesitas, sementara lemak tak jenuh memiliki efek mengurangi resistensi insulin yang baik untuk penderita diabetes.Sedangkan padalauk nabati seperti tahu, tempe, dan kacang-kacangan merupakan sumber protein nabati dan memiliki indeks glikemik yang rendah, sehingga baik untuk dikonsumsi penderita $\mathrm{DM}(\mathrm{ADA}$, 2013). Fungsi protein sangat penting bagi tubuh yaitu sebagai zat pembangun bagi pertumbuhan dan pemeliharaan jaringan tubuh, sebagai pengatur kelangsungan proses di dalam tubuh, dan sebagai pemberi energi melalui proses glukoneogenesis apabila energi kurang tercukupi oleh karbohidrat dan lemak (Kartasa \& Marsetyo, 2000). Asupan protein responden masih kurang karena meninggalkan sisa $\geq 25 \%$.Asupan protein yang tidak sesuai dengan kebutuhan akan mempengaruhi kadar gula dalam darah. Kadar gula darah juga dapat di kendalikan dengan mengkonsumsi makanan dengan IG rendah antara lain buah-buahan, sayuran dan kacang-kacangan yang juga termasuk dalam makanan kaya serat (Azrimaidaliza, 2011). 
Konsumsi sayuran pada penelitian ini masih kurang karena sebagian responden masih meninggalkan sisa makanan berjenis sayur $\geq 25 \%$ yaitu 32 responden. Sayuran merupakan sumber vitamin, mineral dan serat, artinya sebagian responden masih kurang dalam konsumsi serat makanan. Serat makanan yaitu bagian dari tumbuhan yang dapat dikonsumsi dan tersusun dari karbohidrat yang resisten terhadap pencernaan dan absorpsi pada usus halus dengan fermentasi lengkap atau partial pada usus besar. Secara fisis serat dapat dijumpai dalam 2 bentuk, yaitu yang larut dan tidak larut air, dengan konsumsi serat sesuai kebutuhan dapat menimbulkan rasa kenyang akibat masuknya karbohidrat komplek yang menyebabkan menurunnya selera makan dan akhirnya menurunkan konsumsi makan, disamping itu serat juga mengandung kalori rendah sehingga dapat menurunkan kadar gula darah dan lemak dalam tubuh (Arianti et al., 2015).

\section{Daya Terima Makanan Berdasarkan Distribusi Rata-rata Sisa Makanan Secara Keseluruhan}

Pada penelitian ini, responden DM tipe 2 dengan komplikasi yang dirawat inap sudah diberikan edukasi serta konseling mengenai pengaturan pola makan dan menghabiskan makanan yang disajikan oleh rumah sakit, namun dalam praktiknya masih ada yang belum dapat menerapkan sesuai dengan yang telah diberikan. Hal tersebut dapat dilihat dari banyaknya sisa makanan pada diet DM, sisa makanan yaitu makanan yang tidak habis dimakan dan dibuang sebagai sampah (Utari, 2009).

Rata-rata sisa makanan responden secara keseluruhan yaitu bersisa $\geq 25 \%$ sebesar 41 responden (Tabel 3). Data Rata-rata sisa makanan responden secara keseluruhan dan berdasarkan jenis bahan makanan menunjukan daya terima atau asupan makan pada responden masih kurang, paling tidak responden harus mengkonsumsi makanannya dan meninggalkan sisa makanan $<25 \%$ dari yang disajikan oleh rumah sakit, karena makanan yang telah disediakan oleh instalasi gizi sudah diperhitungkan mutu dan jumlah gizinya.

Daya terima makan yaitu kesanggupan seseorang mampu menghabiskan makanan yang disajikan sesuai dengan kebutuhannya dan makanan tersebut habis dimakan tanpa meninggalkan sisa makanan, hal tersebut dapat dilihat dari jumlah sisa makanan serta nilai dari jawaban terhadap pertanyaan yang berhubungan dengan makanan yang dikonsumsi (Uyami et al., 2014). 
Renangtyas (2004) menyatakan jika pasien meninggalkan makanan $>25 \%$ dapat dikatakan sisa makanan tinggi atau banyak dan akan menyebabkan tingkat konsumsi zat gizi defisit. Hal tersebut dapat berpengaruh pada proses penyelenggaraan makanan di rumah sakit.

\section{Daya Terima Makanan Berdasarkan}

\section{Penilaian Terhadap Atribut Makanan}

Kualitas penyelenggaraan makan dapat dilihat pada kepuasan pasien, beberapa hal yang harus diperhatikan yaitu penampilan makanan, cita rasa makanan, kebutuhan alat, ketepatan waktu serta sikap dan perilaku petugas dalam menyajikan makanan secara langsung maupun tidak langsung dapat mempengaruhi selera makan pasien (Suryawati, 2004). Dilihat dari hasil penelitian (tabel 4) menunjukan hasil penilaian terhadap atribut makanan secara keseluruhan mengenai penampilan makanan, rasa makanan, penyajian makanan, tekstur makanan, aroma makanan, dan variasi makanan dalam kategori baik $\geq 80 \%$ yaitu 29 responden (55\%), namun untuk segi rasa mayoritas responden mengatakan makanan rumah sakit tidak seenak makanan biasa yang dikonsumsi dirumah, hal ini dikarenakan penggunaan bumbu sebagai penyedap makanan dibatasi dan disesuaikan dengan keadaan atau kondisi responden. Daya terima terhadap makana rumah sakit dipengaruhi beberapa faktor, menurut Ratnasari (2003) salah satunya yaitu faktor eksternal atau faktor luar individu yang mempengaruhi konsumsi makanan. Porsi yang tepat, penampilan yang menarik, peralatan yang bersih dan waktu penyajian yang tepat akan meningkatkan penilaian terhadap makanan sehingga dapat membangkitkan selera makan responden.

\section{KESIMPULAN}

Daya terima makanan berdasarkan gambaran sisa makanan pada pasien DM tipe 2 dengan komplikasi yaitu tidak baik dengan sisa makanan $\geq 25 \%$. Berdasarkan atribut makanan berada dalam kategori baik dengan nilai $\geq 80 \%$. Hasil penelitian ini menunjukkan bahwa daya terima makanan pasien penyakit DM tipe 2 dengan komplikasi dilihat dari sisa makan pasien kurang baik, oleh karena itu Rumah Sakit Mardi Waluyo Lampung dapat meningkatkan kualitas pelayanan gizi agar tujuan pelayanan gizi rumah sakit dalam membantu mempercepat kesembuhan responden dan meningkatkan derajat kesehatan responden dapat tercapai secara optimal, serta mengoptimalkan edukasi kepada pasien terutama pasien pralansia dan 
lansia agar lebih termotivasi untuk menghabiskan makanan yang diberikan RS.

\section{UCAPAN TERIMA KASIH}

Dalam menyusun TA ini penulis banyak menerima bantuan dari berbagai pihak. Untuk itu, penulis ingin menyampaikan ucapan terima kasih sebesar-besarnya kepada semua pihak yang sudah turut membantu.

\section{REFERENSI}

Almatsier, Sunita. (2008). Persepsi pasien terhadap makanan di rumah sakit (jurnal gizi Indonesia) 1992 vol 2 halaman 87- 96.

American Diabetes Association (2013). The Glycemic Index of Foods. Availableonline:http://www.diabetes.o $\mathrm{rg} /$ foodandfitness/food/planningmeals/the glycemic-index-offoods.html.

Arianti, S. D., Syamsianah, A. and Handarsari, E. (2015) 'Hubungan Kontribusi Lauk Hewani, Nabati dan Sayuran dengan Tingkat Konsumsi Protein dan Zat Besi pada Mahasiswi yang Tinggal di Rusunawa Residence 1 Unimus', pp. 22-28. Available at: agsyams@gmail.com.

Azrimaidaliza (2011) 'Asupan Zat Gizi Dan Penyakit Diabetes Mellitus', JKMA: Jurnal Kesehatan Masyarakat Andalas) (Andalas Journal of Public Health), 6(1), pp. 36-41. doi: 10.24893/jkma.6.1.36-41.2011.

Budiharti, S. (2009). Hubungan pengetahuan gizi dan persepsi pasien tentang makanan dengan sisa makanan di rsud kota salatiga jawa tengah. Skripsi. FIK UNDIP.

Comstock, E. M., St Pierre, R. G., \&
Mackiernan, Y. D. (1981). Measuring individual plate waste in school lunches. Visual estimation and children's ratings vs. actual weighing of plate waste. Journal of the American Dietetic Association, 79(3), 290-296.

Dedoussis, G. V. Z., Kaliora, A. C. and Panagiotakos, D. B. (2007) 'Genes, diet and type 2 diabetes mellitus: A review', Review of Diabetic Studies, 4(1), pp. 13-24. doi: 10.1900/RDS.2007.3.13.

Depkes RI (2009). Profil Kesehatan Indonesia. Jakarta: Depertemen Republik Indonesia

DepKes RI (2013) 'Badan Penelitian dan Pengembangan Kesehatan Kementrian Kesehatan RI. Jakarta':, Laporan Nasional 2013, pp. 87-90.

DinKes (2015) 'Profil Kesehatan Provinsi Lampung', (44).

Galleta GM. (2005). Obesity: Obesity Causes.

https://www.emedicinehealth.com/o besity/article_em.htm\#Obesity $\% 20 \mathrm{Ca}$ u\%09ses.(Diakses 21 September 2019).

Harding, A.-H., Sargeant, L. and Welch, A. (2001) 'Fat consumption and HbA1c levels', Diabetes care, 24(11), pp. 1911-1916.

IDF (2015) International Diabetes Federation. IDF Diabetes Atlas, 7th edn. Brussels, Belgium: International Diabetes Federation, bttp:// www diabetesatlas.org, International Diabetes Federation. doi: 10.1289/image.ehp.v119.i03.

Irawan D.( 2010). Prevalensi dan Faktor Risiko Kejadian Diabetes Melitus Tipe 2 di Daerah Urban Indonesia (Analisis Data Sekunder Riskesdas 2007). (Tesis). Depok: FKM UI

Kartasapoetra. Marsetyo. (2000). Ilmu Giz̧i Korelasi gizi, Kesehatan, dan Produktivitas Kej. Jakarta: Rineka Cipta.

Kemenkes (2013) Pedoman Pelayanan Gizi Rumah Sakit (PGRS), Journal of Chemical Information and Modeling. doi: 10.1017/CBO9781107415324.004. 
Lathifah, L. N. (2017) 'Hubungan Durasi Penyakit Dan Kadar Gula Darah Dengan Keluhan Subyektif Penderita Diabetes Melitus', Jurnal Berkala Epidemiologi, 5, pp. 231-235. doi: 10.1007/3-540-49380-8_16.

Perkeni (2011) 'Konsensus Pengendalian danPencegahan Diabetes Melitus Tipe 2 di Indonesia 2011', Perkeni, p. 78. doi: 10.3732/ajb.1100495.

Priyanto, O.H. (2009). Faktor yang Berhubungan dengan Terjadinya Sisa Makanan pada Pasien Rawat Inap kelas III di RSUD Kota Semarang. Skripsi. Fakultas Ilmu Keolahragaan Universitas Negeri Semarang.

Ramadhani, A, Sapulete, I.M, dan Pangemanan, D.H.C. (2016). Pengaruh Senam Lansia Terhadap Kadar Gula pada Lansia di BPLU Senja Cerah Manado. Jurnal e-Biomedik. 4 (1) : 104-109.

Ratnasari L. (2003). Daya terima makanan dan tinkat konsumsi energi-protein pasien rawat inap penderita penyakit dalam di Rumah Sakit Umum Daerah Kabupaten Cilacap [skripsi]. Jurusan Gizi Masyarakat dan Sumberdaya Keluarga. Fakultas Pertanian Institut Pertanian Bogor.

Renaningtyas, D. (2004). Pengaruh Penggunaan Modifikasi Standar Resep Lauk Nabati Tempe Terhadap Daya Terima Dan Persepsi Pasien Rawat Inap. Jurnal Giri Klinik Indonesia 1(1): 47-50

Saepuloh. (2003). Faktor-faktor yang mempengaruhi daya terima pasien dewasa diit makanan biasa (studi di ruang rawat inap kelas II dan III rumah sakit immanuwl bandung). Undergraduate thesis, Universitas Diponegoro

Salman, Y., Saputri, R. and Ridha, M. R. (2014) 'Faktor-Faktor Yang Berhubungan denganTerjadinya Sisa Makanan Pasien Diabetes Mellitus Di Rumah Sakit Umum Daerah Dr. H.
Moch. Ansari Saleh Banjarmasin', Jurkessia, Vol. IV, N(6), pp. 1-6.

Smeltzer, S. C. et al. (2014) 'Management of Patients With Infectious Diseases', in Brunner and Suddarth's textbook of medical-surgical nursing, pp. 2120-2152. doi:

10.1097/ANA.0b013e3181ec60d3.

Sulistiyanto A.D, Oktia Woro K.H, dan E. R. . (2017) 'Peran Petugas Gizi dalam Memberikan Pelayanan Asuhan Gizi pada Pasien Rawat Inap', Unnes Journal of Public Health, 6(2), pp. 76-83.

Sundari, E, Masdar, H, dan Rosdiana, D, 2015. Angka Kejadian Obesitas Sentral Pada Masyarakat Kota Pekanbaru. JOM FK. 2 (2) : 1-16.

Suryawati, C. (2004). Kepuasan Pasien Rumah Sakit (Tinajauan Teoritis dan Penerapannya Pada Penelitian, Jurnal Manajemen Pelayanan Kesehatan, vol. 7, no. 4, hal. 189-194.

Stanga Z, Zurflüh Y, Roselli M, Sterchi AB, Tanner B, Knecht G. (2003). Hospital Food: A Survey of Patients' Perceptions. Clin Nutr Edinb Scotl, 22 (3): 241-6.

Utari, R. (2009). Evaluasi Pelayanan Makanan Pasien Rawat Inap Di Puskesmas Gondangrejo Karanganyar. Karya tulis ilmiah FIK Universitas Muhammadiyah Surakarta.

Uyami, Hendriyani, H. and Wijaningsih, W. (2014) 'Perbedaan Daya Terima, Sisa dan Asupan Makanan pada Pasien dengan Menu Pilihan dan Menu Standar di RSUD Sunan Kalijaga Demak'.

WHO (2016) Global Report on Diabetes, WHO. doi: 10.1371/journal.pone.0127954.

Wulan, M. and Wahyuni, C. U. (2017) 'Hubungan Dukungan Keluarga Dengan Kualitas Hidup Diabetes Melitus Tipe 2 Di Puskesmas Pademawu.', Jurnal Berkala Epidemiologi, Volume 5 N(July), pp. 240-252. doi: 10.20473/jbe.v5i2.2017.240-252. 